\title{
A framework for managing the regulatory and economic capital of banks
}

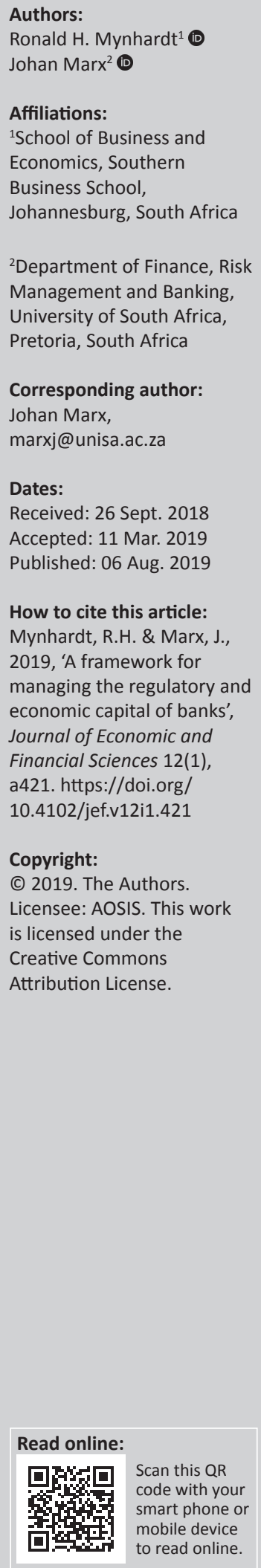

Orientation: Banks face three primary risks, namely credit, market and operational risk. The Basel Committee on Bank Supervision (BCBS) promotes monetary and financial stability by means of their accords, which provides risk mitigation guidelines to banks under the jurisdiction of central banks that are members of the BCBS.

Research purpose: The aim of this study was to develop a framework for participating African banks to enable them to determine their required regulatory capital (RC) and economic capital (EC) because neither the Basel accords nor the central banks involved in this study provided clear guidelines in this regard.

Motivation for the study: During 2016, the banking associations from Kenya, Mauritius, Rwanda, Seychelles, South Sudan, Tanzania, Uganda and Ghana requested assistance with the determination of the EC and RC of their member banks.

Research design, approach and method: The study used pragmatism as a paradigm and a qualitative methodology by using participatory action research (PAR). Directors, non-executive directors, financial officers, internal auditors, risk and compliance officers of banks participated.

Main findings: The participants confirmed their challenges in determining their RC and EC, and hence the focus groups proceeded to systematically and logically develop a framework.

Practical/managerial implications: The resultant framework suggests that greater clarity about the regulatory requirements in each country needs to be provided by their bank supervisors.

Contribution/value-add: The framework enables banks to determine their own RC and EC requirements. However, customised methodologies and reporting structures have to be developed and followed during implementation and validation.

Keywords: Basel II; framework; economic capital; regulatory capital; East Africa; West Africa.

\section{Introduction}

The Basel Committee on Bank Supervision (BCBS) of the Bank of International Settlements (BIS) has assisted banks globally in mitigating risk since 1988 (BIS 2018). The mission of the BIS is to serve central banks in their pursuit of monetary and financial stability, to foster international cooperation in those areas and to act as a bank for central banks (Mostert 2013; Toniolo \& Clement 2005). The shareholding members of the BIS are central banks and monetary authorities (Felsenfeld \& Bilali 2004). Pillar 1 focuses on banks having adequate capital in order to manage their three primary risks, namely credit, market and operational risk. Pillar 2 focuses on the supervisory review process, and Pillar 3 focuses on enhanced disclosure (market discipline) (BIS 2001).

Banks face three primary risks, namely credit, market and operational risk. The BCBS promotes monetary and financial stability by means of their accords, which provides risk mitigation guidelines for banks under the jurisdiction of central banks who are members of the BCBS.

Credit risk is defined by the BIS (2000:1) as 'the potential that a bank borrower or counterparty will fail to meet its obligations in accordance with agreed terms'. In general, the most important source of credit risk is the loans that banks provide to their customers, but there are also several other sources of credit risk. According to the BIS (2000), these include acceptances, interbank transactions, trade financing, foreign exchange transactions, financial futures, swaps, bonds, equities, options, the extension of commitments and guarantees, and the settlement of transactions. 
Market risk is defined as the risk of losses arising from movements in market prices, in particular from financial instruments, foreign exchange and/or commodities (including non-tangible commodities such as electric power) (BIS 2016).

Operational risk is defined by the BIS (2011:3) as 'the risk of loss resulting from inadequate or failed internal processes, people and systems or from external events. This definition includes legal risk, but excludes strategic and reputational risk'. Banks face cyber threats on a daily basis because of hackers attempting to access their computer systems in order to steal data, transfer funds illegally or to disable systems thus denying customers service (Ferguson 2015). Cyber threats are therefore part of the operational risk of a bank.

To date, the BIS provided three accords (often referred to as Basel I, Basel II and Basel III) to ensure banks have adequate capital, regulatory supervision and market discipline. Basel IV was expected to be released by 2016 for implementation from 2019 (Gomez 2016:6).

In order to ensure adequate capital, banks have to continuously perform asset and liability management (ALM), thus ensuring they manage any possible mismatch between their assets and liabilities. Failure to do so could result in technical bankruptcy, threatening the sustainability of a bank and resulting in its customers losing their cash deposits. Any such closure could happen if there is a so-called run on the bank, because its clients are able to withdraw their cash quicker than the bank's ability to raise additional equity in order to restore its technical insolvency.

The capital adequacy requirements include both regulatory capital (RC) and economic capital (EC). Basel II, in particular, aims to set more risk-sensitive minimum capital requirements so that RC is adequate yet closer to a bank's EC (Caruana 2005).

Regulatory capital refers to three tiers of capital that would be eligible for adequacy purposes. The RC requires that a bank must have at least $8 \%$ of the value of its risk-weighted assets available as reserves. This is also referred to as the capital ratio of banks (Federal Reserve 2003:396).

Elizalde and Repullo (2007) define economic capital as:

The level of capital chosen by shareholders at the beginning of each period in order to maximize the value of the bank, taking into account the possibility that the bank will be closed if the losses during the period exceed the initial level of capital. (p. 88)

According to Ojwang (2015), central banks in Africa have to update their regulatory frameworks. However, the Basel accords do not provide specific guidelines about how the RC and EC of banks must be determined. Equally, not all banks have the capability to implement the Basel accords. Furthermore, the governance, management and internal processes of banks differ significantly from one another depending on their size, types of financial services offered, as well as whether they are foreign-owned or locally owned banks.

In order to address the above-mentioned challenges, five focus groups were held (see Table 1), and these started with the completion of structured questionnaires by the participants in order to determine their current approaches to capital adequacy. The focus groups consisted of representatives from banks and banking associations from Kenya, Mauritius, Rwanda, Seychelles, South Sudan, Tanzania, Uganda and Ghana. The aim of the focus groups was to construct a framework that could be used to manage their RC and EC. The successful implementation would enhance their sustainability and enable them to transact with international banks requiring compliance with Basel capital adequacy requirements as part of managing their risk.

\section{Objective}

Risk and compliance officers of banks and banking associations from East and West African countries requested assistance with the determination of their RC and EC in accordance with the Basel accords.

The objective of this study was thus to develop a framework that could be used by African banks for managing the implementation of their capital adequacy requirements of the Basel II and Basel III accords.

Although some of the central banks of the countries involved in this study are involved in deliberations for the creation of an African monetary union, this aspect was not part of the brief of the participants and is therefore beyond the scope of this study.

TABLE 1: Number of participants from East and West African countries.

\begin{tabular}{|c|c|c|c|c|c|c|c|c|}
\hline Country & DIR & $\mathrm{COs}$ & RMOs & FOs & IAs & NEDs & IBRs & Total \\
\hline Kenya & 1 & 5 & 6 & 8 & 5 & 1 & & 26 \\
\hline Mauritius & - & - & - & 2 & - & - & - & 2 \\
\hline Rwanda & - & - & - & - & 1 & - & - & 1 \\
\hline Seychelles & - & - & - & - & 2 & - & - & 2 \\
\hline South Sudan & - & 1 & 1 & - & 1 & - & - & 3 \\
\hline Tanzania & - & 3 & 4 & 2 & 4 & 2 & - & 15 \\
\hline Ghana & 2 & 9 & 9 & 8 & 2 & 3 & 2 & 35 \\
\hline Total & 5 & 21 & 23 & 24 & 19 & 8 & 4 & 104 \\
\hline
\end{tabular}

DIR, directors; COs, compliance officers; RMOs, risk management officers; FOs, financial officers; IAs, internal auditors; NEDs, non-executive directors; IBRs, industry body representatives. 
The remainder of the article is organised as follows. The 'Literature review' section provides the setting or context of the study by reviewing researches that have been conducted in order to address the challenges posed by Basel accords. The 'Research methodology' section explains the methods used in this study. The 'Results' section presents the results obtained in this study. The next section presents the framework proposed by the focus groups, and the final section; 'Conclusion' provides the conclusion of this study.

\section{Literature review}

According to Ojwang (2015), the Central Bank of Kenya realised it needed to adopt global best practices in bank supervision, such as the revised Basel Core Principles for Banking Supervision, not only to ensure the financial stability and sustainability of their banks but also to respond to changes in their local, regional and global operating environments. Importantly, this suggests that adopting global best practices would also improve the ability of African countries to become economically better integrated in world trade and finance.

Therefore, the viewpoint of the central banks of the countries involved is that the challenges in implementing the Basel accords have to be overcome.

Several researchers have attempted to find solutions to the challenges posed by the Basel accords. The purpose of this section is to provide context by reviewing the challenges banks face in determining the RC and EC of banks in order to adequately mitigate the risks they face and yet comply with the Basel requirements. The discussion will be structured according to the challenges faced globally, followed by a discussion of the challenges faced by banks in Africa. The discussion will be done according to the sequence in which the research results were published.

\section{Challenges with the implementation of Basel globally}

Jones (2000:35-58) developed techniques for banks which may be used to achieve 'regulatory capital arbitrage' by means of securitisation and other financial innovations, and in the process reducing their RC requirements substantially with little or no corresponding reduction in their overall economic risks. These methods are used routinely to lower the effective risk-based capital requirements against certain portfolios to levels well below the Basel Capital Accord's nominal $8 \%$ total risk-based capital standard.

According to Caruana (2005), internationally active banks are centralising key systems and functions, yet bank regulation is predominantly a national responsibility.

Banks may evaluate their risk internally or for the purpose of satisfying their regulator. Basel II is not prescriptive about internal analysis and does not provide detailed regulations about it. Kundisch et al. (2007) conclude that there is a possibility of reducing the complexity of the Basel accords and saving costs by implementing a management system based on Basel II data requirements, and they argue for a convergence of internal analysis and external reporting requirements in future.

The implementation of Basel II is also very expensive (Kundisch et al. 2007). According to Herring (2007), Basel II has a number of irreconcilable objectives.

A survey conducted by the Financial Stability Institute (FSI) during 2008 confirmed a skewed implementation among various continents and countries. Out of the 57 countries that planned to implement Basel II by the end of 2008, 34 were from Europe, 10 from Asia, 8 from the Middle East and 3 from the Americas (KPMG 2012).

Many banks have underestimated the size, scope and cost required to implement the Basel rules (Härle et al. 2010). According to these researchers, it would cost a mid-sized European bank between $€ 45$ million and $€ 70$ million to implement Basel II in order to achieve regulatory compliance, and this excludes the cost of materially improving a bank's risk, financing, capital funding and balance sheet management.

Härle et al. (2010) point out that differences in the governance, risk strategy, management, information and communication technology (ICT) processes and management information systems are too substantial to make a universal implementation of Basel III possible.

The implementation of the Basel accords is data-intensive (IBM 2011). The implication is that the implementation of any one of the Basel accords requires significant computer facilities, well-designed processes and competent staff to implement and maintain systems for data capturing, analysis and storage.

Although Basel II represents an improvement over Basel I because of its more responsive and individually measured calculations of risk, it introduced a greater degree of complexity (BIS 2012; Gomes \& Khan 2011; Mostert 2013; Schoenbaum 2012).

As a result of the above-mentioned challenges, the Basel I, Basel II and Basel III accords are not being implemented consistently by all banks. The Basel accords were designed primarily for banking institutions operating internationally (BIS 2014).

According to Blundell-Wignall, Atkinson and Roulet (2014), the main hallmarks of the global financial crisis of 2008 were too-big-to-fail institutions taking on too much risk with other people's money, hence excess financial leverage and default pressure resulting from contagion and counterparty risk. These researchers asked whether the Basel accords addressed 
these issues effectively. The Basel accords have useful elements, notably a leverage ratio, a capital buffer, a proposal to deal with pro-cyclicality through dynamic provisioning based on expected losses, as well as liquidity and stable funding ratios. However, the Basel risk-weighting and the use of internal bank models for determining them lead to systematic regulatory arbitrage that undermines its effectiveness. Empirical evidence about the determinants of the riskiness of a bank (measured in the Blundell-Wignall study by the distance to default) shows that a simple leverage ratio vastly outperforms the Basel Tier 1 ratio. Furthermore, business model features (after controlling for macro factors) have an influence on the effectiveness of the Basel III accord. Derivatives' origination and prime broking carry vastly different risks to core deposit banking. Where such differences are present, the Basel accords do not make sense by adopting a one-size-fits-all approach to capital rules. Capital rules make more sense when fundamentally different businesses are separated.

Therefore, banks globally grapple with challenges during the implementation of the Basel II and Basel III accords.

\section{Challenges with the implementation of Basel faced by African banks}

In addition to the challenges described above, and as will be described below, African banks face challenges such as a lack of technical capacity, whether to use the simplified standardised approach or the more complex approach, the competitive advantage foreign banks have in implementing Basel compared to locally owned banks, unique economic conditions, limited resources and limited international integration.

Makuna (2005:1) argues that, although the cost of compliance might have been too high, there is still a definite need for regulatory authorities and supervisory activities in South Africa. Makuna (2005:1) further concluded that the challenge to banks in South Africa was to ensure compliance with acts and regulations in their organisations at an acceptable cost. The cost of compliance could, however, be reduced by up to $40 \%$ if a single financial services regulator existed, tax rebates were offered, capital reductions were allowed, the compliance function could be outsourced and if changes to section 60 of the South African Banks Act (Act 94 of 1990) were implemented (Marx \& Mynhardt 2011).

Regulators from low-income countries (LICs) indicated that they prefer the standardised approach for the implementation of the Basel accords, but they also face the challenge that they do not have domestic credit rating agencies yet (FSI 2008). At the time of this research, the LICs surveyed indicated that they intended following a more gradual approach to the implementation of Basel and using a simplified standardised model.

Alexander and Sheedy (2008) proposed a methodology for stress testing for market risk purposes in terms of Basel II, which incorporates both volatility clustering and heavy tails. They found that stress test results should have little effect on current levels of foreign exchange RC, which are required of banks.

Gottschalk (2010) concludes that the Basel rules do not only influence bank performance or the macro-economy of a country but also influence the structure of the banking system and its credit patterns, with potential negative implications for the development of finance in developing countries. Gottschalk also highlights the implementation challenges of Basel II for developing countries, citing that the implementation of Basel II absorbed most of the resources and resulted in very little being available to address broader development-related issues.

According to Gottschalk (2010), some African countries have no foreign banks (e.g. Ethiopia); yet, others have foreign banks only, for example Lesotho and Botswana. As banks operating internationally prefer to implement the Basel accord globally, such countries would have to deal with Basel issues despite deciding not to implement any of the Basel accords. Foreign banks have the benefit that they may divest and discontinue their operations in a country should they find the national regulations inconvenient to them.

By 2012, only four countries from Africa had implemented Basel II, namely South Africa, Mauritius, Namibia and Tanzania (KPMG 2012).

The KPMG (2012) survey of 14 African countries revealed that some countries are facing challenges as a result of ICT systems (e.g. Ghana), while others are trusting that the implementation of the International Financial Reporting Standards (IFRS) will contribute to the implementation of the Basel accords (e.g. in Nigeria and Senegal).

According to Frait and Tomsik (2014), emerging markets have specific differences, which set them apart from developed economies, namely:

- The financial markets of emerging economies are typically more volatile than those of large advanced economies.

- The gross domestic product (GDP) of emerging markets is higher on average than that of advanced economies.

- Emerging markets typically experience stronger credit growth than advanced economies, because the financial sectors of emerging markets are in the process of financial deepening.

- Emerging markets usually have lower credit ratings and shallower government bond markets than advanced economies, which in some cases imply a lack of highquality liquid assets.

According to Veron (2014), some banks in emerging markets and developing economies display gaps in their capacity and governance that prevent them from implementing the Basel rules properly. 
Nyantakyi and Sy (2015) found that most regulatory and supervisory authorities in Africa are still using the Basel I accord. The bank regulators in LICs reported a lack of technical capacity to validate and monitor the more complex models (such as the F-IRB and A-IRB) proposed by Basel II. According to the FSI (2008), most of the LICs decelerated the implementation of Basel during 2006-2008 because of technical difficulties and a lack of human skills and resources.

African banks are not as integrated with global finance as their counterparts from other continents. This is partially explained by the complexity of Basel II and Basel III (Nyantakyi \& Sy 2015).

The simplified standardised approach proposed by Nyantakyi and Sy (2015) would allocate fixed risk weights for different categories of assets which are predetermined by the regulatory authorities. However, foreign banks in these LICs intended implementing more complex models, aligned to their head office requirements. This poses a challenge to the supervisory power of the regulators and results in double reporting for foreign banks. Foreign banks nevertheless gain a competitive advantage (because of being a preferred bank with reduced counterparty risk as a result of complying with Basel II) to the detriment of local banks, which results in bank concentration, skewed credit provision away from small and medium enterprises (SMEs) and reduced bank stability.

Criticisms raised against the Basel rules include following a one-size-fits-all approach and the opportunity costs for banks as a result of $\mathrm{RC}$ which cannot earn the same return as the EC. Also, not all banks have clear frameworks for the implementation of Basel II or Basel III. Although the accords indicate how banks should ensure their sustainability by means of RC and EC, they do not prescribe how and who should determine the levels of RC and EC.

By 2016, banks and bank supervisors from East and Western African countries expressed a need for a framework for determining their RC and EC in accordance with the Basel requirements.

In summary, African banks who have not yet implemented Basel II or Basel III face ICT and human resource challenges and do not have the know-how required for implementation. Equally the implementation is complex and expensive, and the circumstances in Africa are vastly different from those in developed countries.

None of the research to date had addressed the issue of what framework banks in Africa could follow in order to determine the RC and EC in accordance with Basel II or Basel III accords.

\section{Research methodology}

The study followed a qualitative approach and used participatory action research (PAR) as methodology.
Participatory action research was appropriate for this research because it is a recognised research methodology aimed at both knowledge creation and at improving professional practice among the participants, by involving them in focus groups (McNiff \& Whitehead 2016:20). Evidence was needed about an ongoing process of change, namely the adoption of the Basel III accord by the banks of participating African countries. According to McGarvey (2007:1), PAR promotes learning among the people closest to the change, in this case the representatives from the various participating banks.

The participating banks have implemented different levels of Basel - some have implemented Basel II and others are in the process of implementing Basel III, while some have suspended the implementation of Basel II because of the complexity of implementation. Hence, the need for a framework for the implementation of the capital adequacy requirements of Basel II was identified.

The participants comprised directors (DIR), compliance officers (COs), risk management officers (RMOs), financial officers (FOs), internal auditors (IAs), non-executive directors (NEDs) and industry body representatives (IBRs) of banks from East and West African countries. The East African countries that participated are Kenya, Mauritius, Rwanda, Seychelles, South Sudan, Tanzania and Uganda. The West African country that participated is Ghana. Five focus groups were held with representatives from the same institutions, but from different directorates each time in attendance, as summarised in Table 1.

The participants were assured of their safety and anonymity, their participation occurred with informed consent and participants could withdraw at any stage, if they preferred to do so, without any consequences.

\section{Three distinct phases were followed:}

- a questionnaire completed at the beginning of each session

- a research problem clarification session

- the solution session.

According to McNiff and Whitehead (2016:168), one may use questionnaires as one of the methods of data collection for action research. The questionnaire aimed to determine the features of the participating banks from East and West Africa and to assess the status quo regarding their Basel implementation, and their capital adequacy determination in particular. Hence, each of the participants completed a structured questionnaire at the beginning of each of the focus group sessions to ensure interpretations were correct and to extract valid data, yet have a $100 \%$ response rate. Therefore, each of the participants submitted his or her completed questionnaire to the facilitator.

The data collected by means of the questionnaire were summarised using descriptive statistics, and the focus groups clarified their challenges and proceeded to systematically 
and logically formulate an actionable framework for the determination of their RC and EC. For the purpose of this article, the statistics of the data collected by means of the questionnaires were aggregated. The Results section describes the data that were collected.

Specific information on capital management was obtained from the banks in the different countries by way of the following questions:

- Is your bank a foreign-owned bank or a locally owned bank in the country?

- Have you implemented Basel II in full, partially or not at all in your bank?

- Does your bank calculate RC for credit, market and operational risk?

- Is your bank using the basic or more advanced approaches to calculate credit, market and operational risk?

- Does your bank calculate RC for external use (to meet regulatory requirements) only or also internal use?

- In your bank, who is responsible for the calculation of RC requirements: the finance department, the risk management department, the compliance department or a separate department?

- Does your bank calculate and manage EC?

- Do you think it is necessary to calculate EC in a bank?

- In your bank, who is responsible for the calculation of EC requirements: the finance department, the risk management department, the compliance department or a separate department?

- Which particular department in a bank should be responsible for managing the $\mathrm{RC}$ and $\mathrm{EC}$ ?

\section{Results}

The following results were obtained in this study.

\section{Foreign-owned and locally owned banks}

Figure 1 indicates the proportion of locally owned banks to foreign-owned banks of the participants.

The majority of the participating banks indicated that they were locally owned. During the focus group discussions,

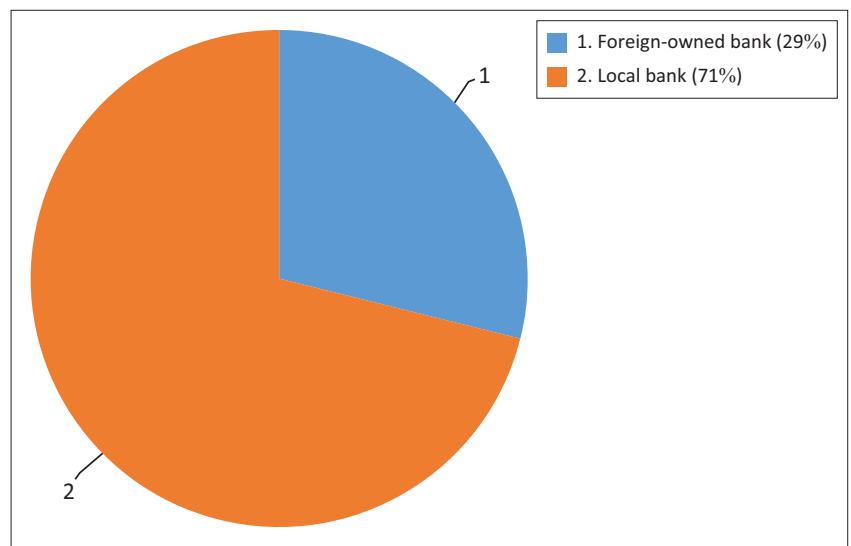

FIGURE 1: Foreign-owned and locally owned banks. these locally owned banks indicated that they do not have the benefit of the expertise from a foreign holding company to assist them with the implementation of Basel II compared to foreign-owned banks.

\section{Level of Basel implementation}

Figure 2 indicates the level of implementation in participating banks.

The majority of participating banks indicated that the Basel requirements were in various stages of implementation with a smaller portion indicating full implementation. During the focus group discussions, full implementation was indicated by the foreign-owned banks, while the vast majority of locally owned banks indicated partial implementation. This showed a close correlation to the data obtained in 'Foreign-owned and locally owned banks' section above.

\section{Level of calculating regulatory capital for credit, market and operational risk}

Figure 3 indicates the level of calculating RC for credit, market and operational risk in banks.

The participating banks indicated that the calculation of credit risk and operational risk for regulatory purposes was performed. However, only a small portion of the banks calculated market risk. During the focus group discussions,

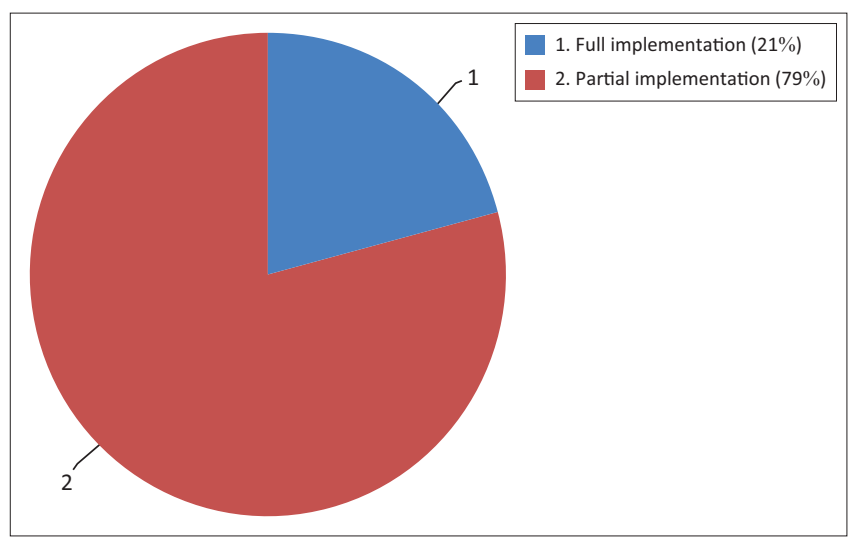

FIGURE 2: Level of Basel implementation.

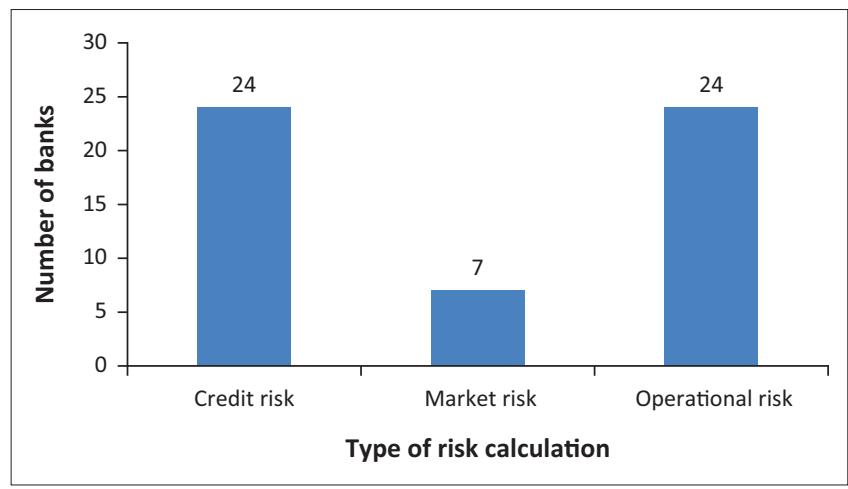

FIGURE 3: Number of banks already calculating regulatory capital for credit, market and operational risk. 
these banks indicated that speculative trading in financial instruments was not allowed by the boards of these banks.

\section{Approaches used to calculate credit, market and operational risk}

Figure 4 indicates the approaches used to calculate credit, market and operational risk by the participating banks.

The majority of the participating banks indicated that the basic approach was used for the calculation of credit risk, market risk and operational risk. During the focus group discussions, the foreign-owned banks indicated that their use of the more advanced approaches was possibly as a result of their ICT capabilities and the expertise of their financial staff members.

\section{Purpose of calculating regulatory capital}

Figure 5 indicates the purpose of calculating $\mathrm{RC}$ of the participating banks.

The majority of the participating banks indicated that the calculation of regulatory credit risk, market risk and operational risk was only performed purely to meet regulatory requirements. Some of the foreign-owned banks indicated the risk calculation was used for internal purposes only because their holding companies held them to higher standards than the local regulatory requirements.

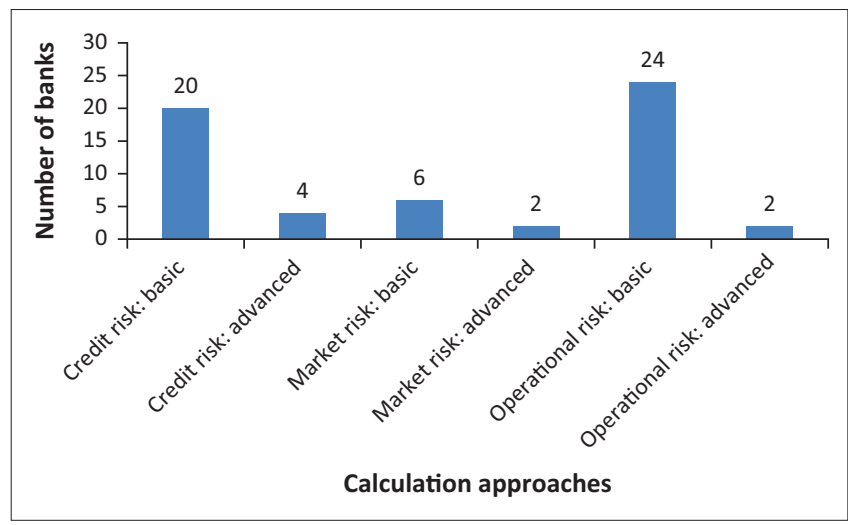

FIGURE 4: Approaches used to calculate credit, market and operational risk

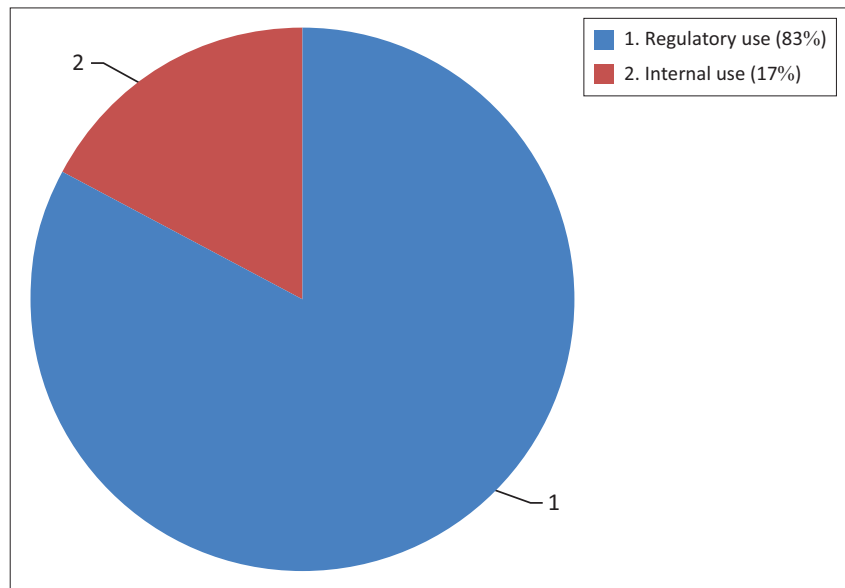

FIGURE 5: Purpose of calculating regulatory capital.

\section{Responsibility for calculations}

Figure 6 indicates bank departments responsible for the calculations mentioned in 'Purpose of calculating regulatory capital' section above.

The results show that $67 \%$ of the participating banks held the finance department responsible for the calculations of regulatory requirements. In $25 \%$ of the cases of participating banks, the risk department was responsible, and in the minority of participating banks, either the compliance department or another department was responsible for these calculations. The reason given for this distribution was that the finance department produced the financial data and was therefore the more logical place to perform these calculations.

\section{Calculation of economic capital}

Figure 7 indicates which of the banks calculated EC as part of its capital management activities.

The majority of participating banks (75\%) indicated that EC was not calculated in the management of capital in these banks. Again, the majority of foreign banks performed these calculations and actually used it in the capital management of the bank.

\section{Necessity to calculate economic capital}

Figure 8 indicates which of the banks deemed it necessary to calculate EC as part of their capital management activities.

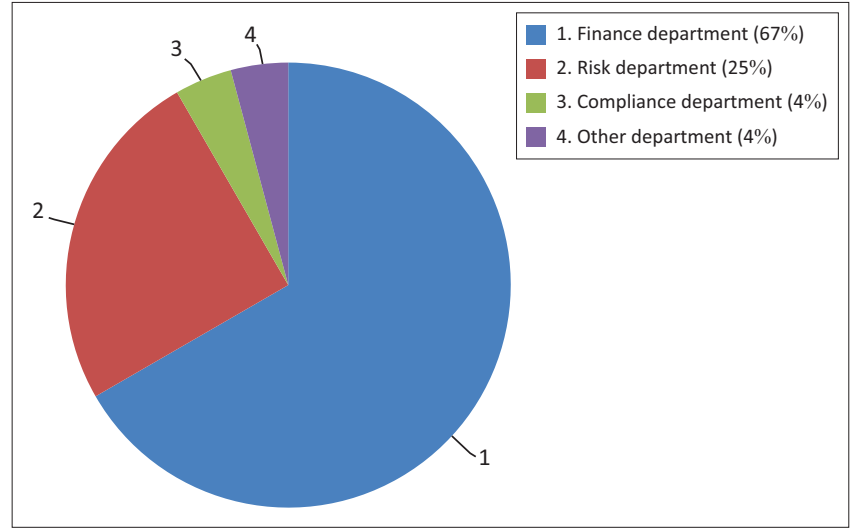

FIGURE 6: Responsibility for calculations.

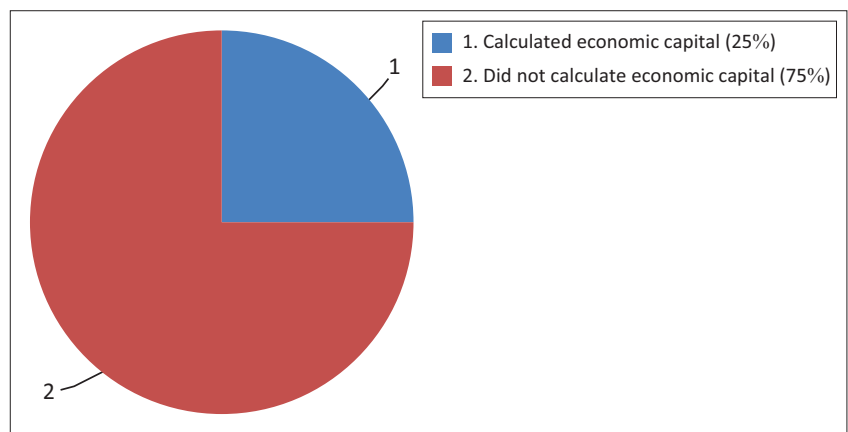

FIGURE 7: Calculation of economic capital. 


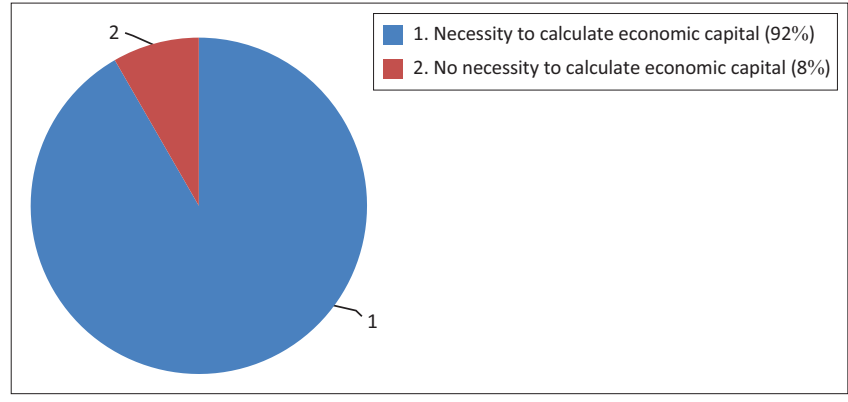

FIGURE 8: Necessity to calculate economic capital.

The majority of banks confirmed that the calculation of EC was necessary in the management of capital in these banks.

\section{Responsibility for economic capital calculations}

Figure 9 indicates bank departments responsible for the calculations mentioned in 'Calculation of economic capital' section above.

Again, the results show that the finance department was responsible for the majority of EC calculations in $67 \%$ of the participating banks. In some banks, the risk department was responsible, and in a few banks, the compliance department. The reason provided by the focus groups for this distribution was once again that the finance department produced the financial data and was therefore the more logical place to perform the calculations.

\section{Need for a central capital management department}

Figure 10 indicates whether the banks were of the opinion that a central capital management department was necessary.

The results indicate that the majority of the participatory banks were of the opinion that a central capital management department was necessary and that this would add value to the efficient management of capital in a bank.

Based on the above data, the focus group proceeded to clarify their issues in determining their RC and EC, followed by a discussion of compiling and validating a framework for the determination of their RC and EC in focus groups. The focus groups recommended the following framework.

\section{Recommended framework}

As the minority of banks reported that they calculated RC and EC because of the challenges it posed, and because there were differences in terms of the unit that had to calculate these figures on a continuous basis, it was decided that a more consistent procedure needed to be developed that could assist both the participating banks in East and West Africa, as well as the bank supervisory sections of their central banks.

The focus groups considered the following issues regarding the determination of the RC and EC of their banks:

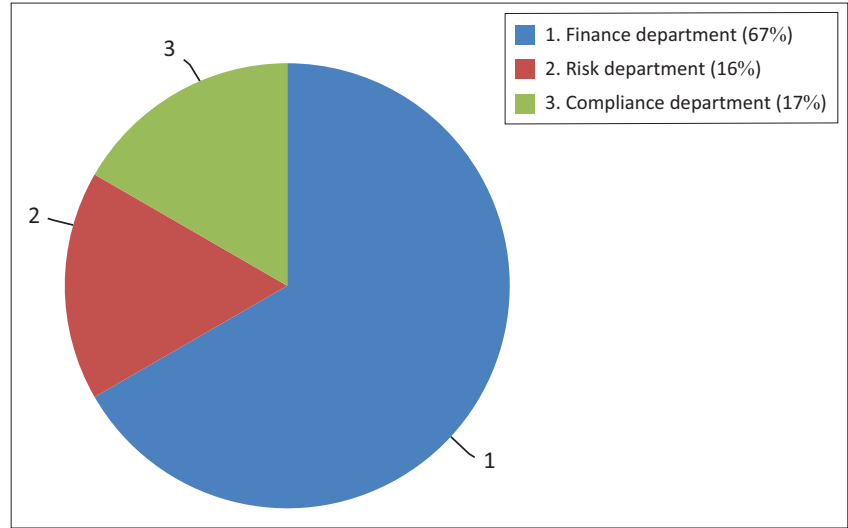

FIGURE 9: Responsibility for economic capital calculations.

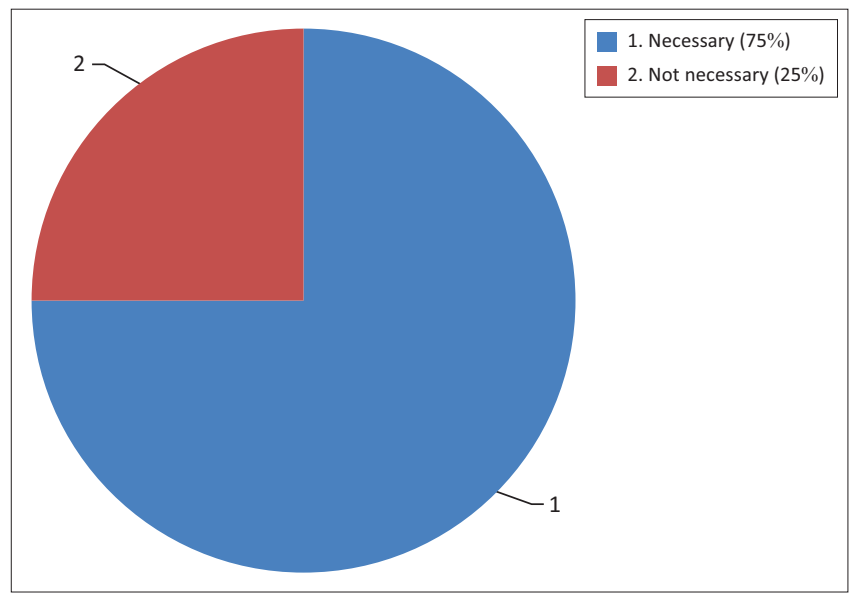

FIGURE 10: Need for a central capital management department.

- What steps need to be followed in estimating the RC of the bank in view of its credit, market and operational risk?

- What steps need to be followed in estimating the EC of the bank in view of its credit, market and operational risk?

- Should the RC and EC estimates be validated and consolidated?

- At what stage will the reporting requirements regarding the RC and EC be required?

- At what stage will the responsible staff members, IT systems and reporting structures be determined?

The procedure firstly comprises specific research activities regarding the regulatory requirements that have to be performed. Secondly, based on the regulatory requirements, a framework consisting of a further four stages was proposed in order to determine the RC and EC. Figure 11 details the recommended implementation framework.

Figure 11 shows that the implementation framework consists of five steps. In step 1, the specific regulatory requirements have to be identified. The framework then divides into three work streams, namely an $\mathrm{RC}$ requirements stream, an EC stream, and a validation and reporting stream.

The RC and EC streams follow the same steps from step 2-5. In both streams, the second step is the identification of the 


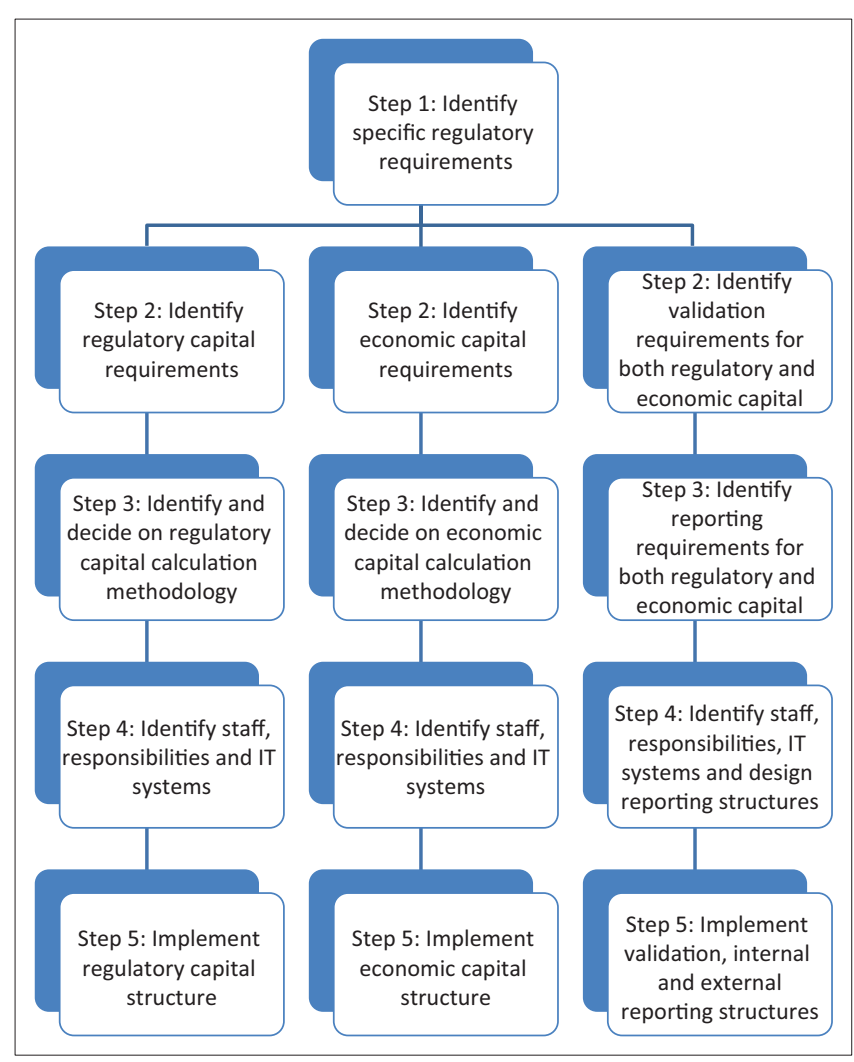

FIGURE 11: Recommended implementation framework.

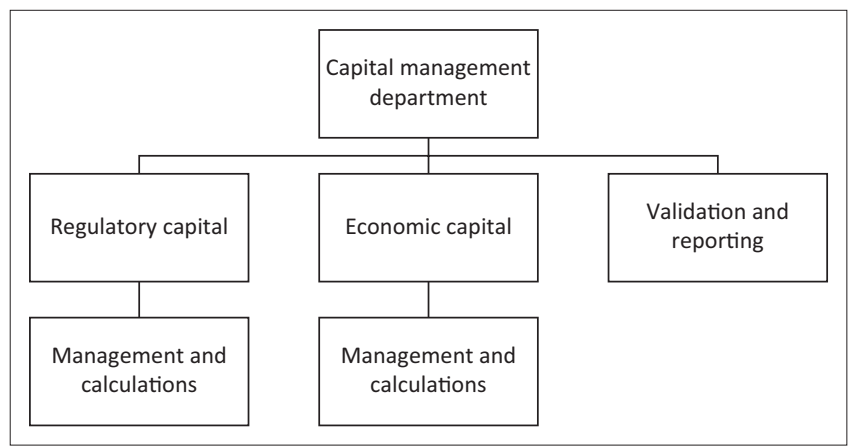

FIGURE 12: Proposed capital management department.

particular capital requirement. Step 3 identifies the particular capital calculation methodology that the bank should employ. Step 4 is the identification of relevant staff, responsibilities and applicable information technologies. Step 5 is the implementation of the particular capital structure.

The third stream comprises the validation of all the capital requirements (step 2 ). In step 3 , the reporting requirements are identified. Step 4 is the identification of relevant staff, responsibilities and applicable information technologies for reporting purposes. Step 5 is the implementation of the relevant supporting structures.

The focus groups validated the proposed implementation framework detailed above, and following further discussions in the various focus groups, a capital management department as part of the financial department was proposed, as detailed in Figure 12.

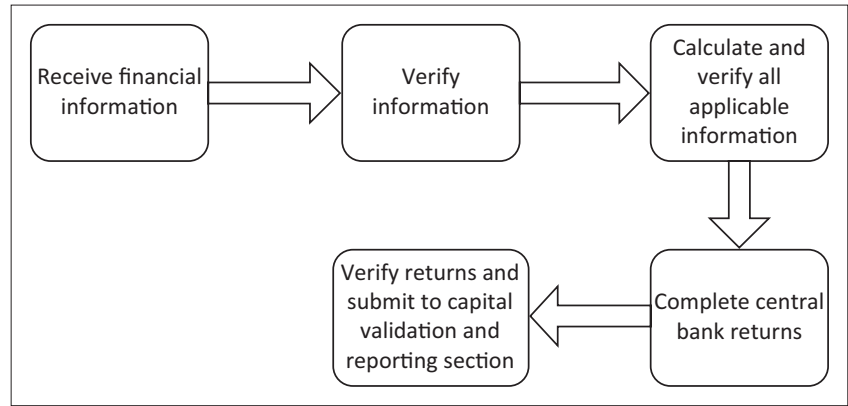

FIGURE 13: Workflow of the regulatory capital management.

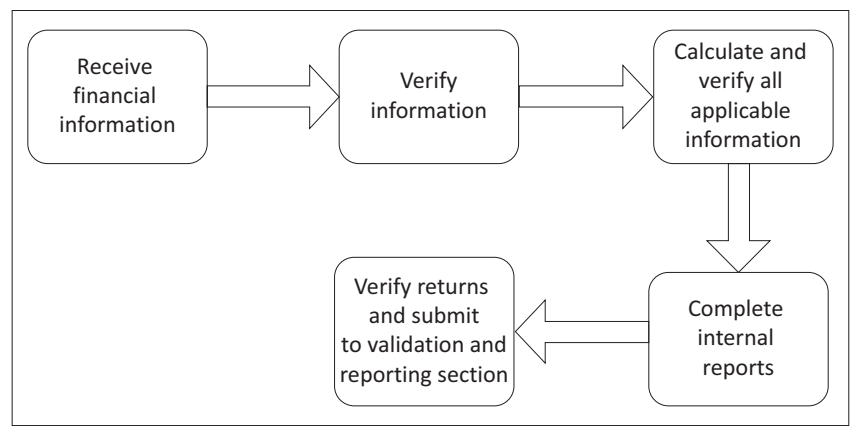

FIGURE 14: Workflow of economic capital management.

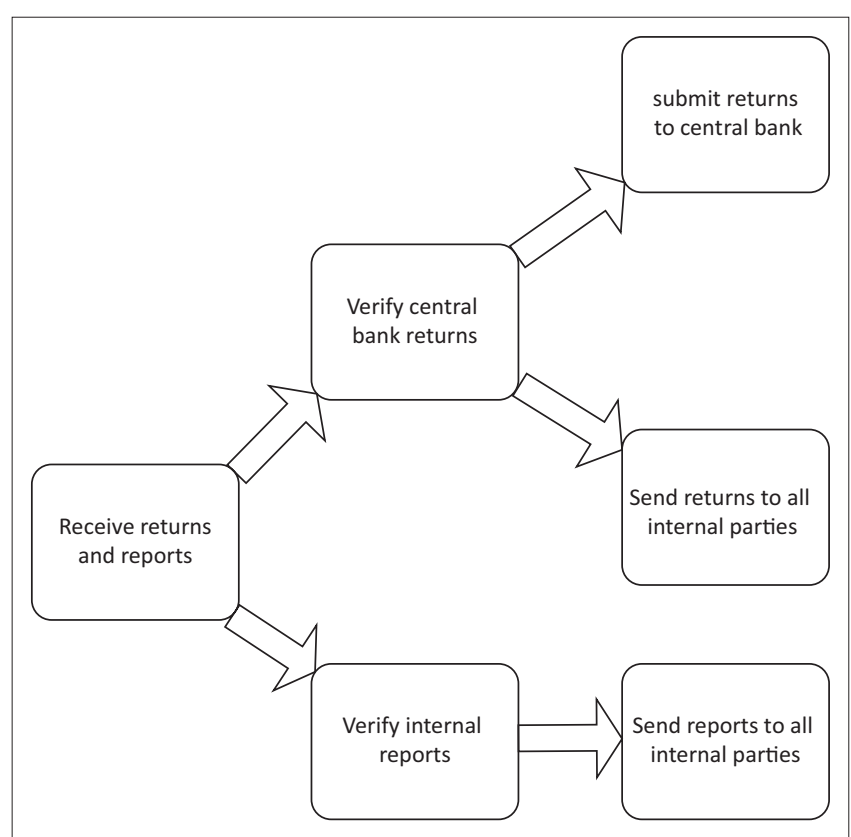

FIGURE 15: Workflow of capital reporting.

The proposal is that a capital management department within the finance department be implemented to accommodate the framework as stipulated in Figure 12. The advantage of this structure is that all the capital management activities of the bank are housed in one department and that the calculations, validations and reporting are performed in a consistent manner. The workflow of this department is detailed in Figures 13-15.

\section{Conclusion}

The research problem of this study was whether a generic framework could be developed to assist African banks with the management of their RC and EC adequacy requirements. 
The BCBS of the BIS assists banks globally in mitigating their three primary risks, namely credit, market and operational risk.

Banks have to perform ALM continuously in order to ensure they manage any possible mismatch between their assets and liabilities. Basel II, in particular, aimed to set more risksensitive minimum capital requirements so that $\mathrm{RC}$ is both adequate and closer to EC (Caruana 2005). The capital adequacy requirements include both RC and EC.

Neither the Basel II and Basel III accords, nor the central banks of the countries involved, provide clear guidelines about how the RC and EC of banks need to be determined. In view of this challenge, the banking associations of the countries involved requested assistance in designing a framework for the determination of the RC and EC of their member banks.

However, the governance, management and internal processes of banks differ significantly from one another, depending on their size, types of financial services offered, as well as whether they are foreign-owned or locally owned banks. Furthermore, not all banks have the capability to implement the Basel rules.

A structured questionnaire was completed by the representatives from the participating banks in East and West Africa who attended focus groups on how to implement the Basel II rules regarding RC and EC. Banks have implemented different ways and used different units to determine their RC and EC. They also faced ICT and HR challenges in this regard and were of the opinion that they needed greater clarity from their bank supervisory units of their central banks, hence the need for a framework for the determination of their $\mathrm{RC}$ and EC. According to the literature, implementing Basel II is both complex and expensive.

The participants completed a questionnaire, the participants articulated their issues and the participants proceeded in focus groups in order to arrive at the proposed framework for the implementation of the Basel II rules regarding RC and EC adequacy.

The resultant framework suggests that greater clarity about the regulatory requirements in each country needs to be provided by their bank supervisors; the capital management sections of the banks must be able to determine their own RC and EC requirements, and these needed to be validated; appropriate methodologies have to be developed; staff, governance and IT systems have to be deployed, as well as reporting requirements defined; and reporting structures have to be determined, followed by implementation and validation.

The successful implementation of the framework will primarily assist banks in ensuring their own economic sustainability because they should have adequate RC and EC to be able to better mitigate the risks they face and improve their resilience in response to any financial crises that may occur, thus enhancing financial stability as envisaged by the Basel accords. A secondary benefit would be that they become more acceptable counterparties in the international context who are able to manage their market, credit and operational risk. The benefit to central banks of banks adopting the capital adequacy requirements of the Basel accords would be improved resilience from financial crises, enhanced monetary and financial stability, as well as increased international fund flows.

Validation of a proposed solution is an optional step in PAR. Therefore, further research required would be to involve the central banks in order to refine, validate and promulgate the framework, as well as to develop appropriate rules specifically for banks in each of the respective East and West African countries that could be implemented in a staggered approach and that would eventually make the implementation of one of the Basel accords more viable. Such rules will need to take into account their envisaged African monetary union, the business models employed, risk profiles and banking operations. The competencies required, and the ways in which the training needs of banks in East and West Africa may be addressed, also warrant further research.

\section{Acknowledgements}

The representatives from the various banks and central banks involved in the study have made this research possible.

\section{Competing interests}

The authors declare that they have no financial or personal relationships that may have inappropriately influenced them in writing this article.

\section{Authors' contributions}

R.H.M. contributed to the data collection, focus groups, graphs and analysis. J.M. contributed to the abstract, introduction, literature review, summary and conclusion sections.

\section{Ethical considerations}

The University of South Africa (UNISA) started implementing ethical clearance during 2016 and at the time of writing had not issued permit numbers yet. Prof. R.H. Mynhardt (Southern Business School) undertook the data collection during 2014-2016. During 2017 Prof. J. Marx got involved and wrote the literature review, abstract, introduction, conclusion and did the references. The University of South Africa provided a letter permitting Prof. J. Marx to undertake the afore-mentioned activities as part of a broader research project about Basel implementation in African countries.

\section{Funding}

This research received no specific grant from any funding agency in the public, commercial, or not-for-profit sectors. 


\section{Data availability statement}

The data used in this study are available from Prof. R.H. Mynhardt on request.

\section{Disclaimer}

The views and opinions expressed in this article are those of the authors and do not necessarily reflect the official policy or position of any affiliated agency of the authors.

\section{References}

Alexander, C. \& Sheedy, E., 2008, 'Developing a stress testing framework based on market risk models', Journal of Banking \& Finance 32(10), 2220-2236. https://doi. org/10.1016/j.jbankfin.2007.12.041

BIS (Bank for International Settlements), 2000, Basel Committee on Banking Supervision. Principles for the management of credit risk, viewed 05 September 2016, from http://www.bis.org/publ/bcbs75.pdf.

BIS (Bank for International Settlements), 2001, The new Basel Capital Accord: An explanatory note, viewed 26 September 2018, from https://www.fsa.go.jp/inter/ bis/bj_20010117_1/1g.pdf.

BIS (Bank for International Settlements), 2011, Basel Committee on Banking Supervision. Principles for the sound management of operational risk, viewed 05 September 2016, from http://www.bis.org/publ/bcbs195.pdf.

BIS (Bank for International Settlements), 2012, Basel II: Revised international capita framework, viewed 08 September 2016, from www.bis.org/publ/bcbsca.htm

BIS (Bank for International Settlements), 2014, Impact and implementation challenges of the Basel Framework for emerging market, developing and small economies, viewed 27 February 2017, from http://www.bis.org/bcbs/publ/wp27.pdf.

BIS (Bank for International Settlements), 2016, Basel Committee on Banking Supervision. Standards: Minimum capital requirements for market risk, viewed 05 September 2016, from http://www.bis.org/bcbs/publ/d352.pdf.

BIS (Bank for International Settlements), 2018, History of the Basel Committee, viewed 26 September 2018, from https://www.bis.org/bcbs/history.htm.

Blundell-Wignall, A., Atkinson, P.E. \& Roulet, C., 2014, 'Bank business models and the Basel system: Complexity and interconnectedness', OECD Journal: Financia Market Trends 7(2), 1-26. https://doi.org/10.1787/fmt-2013-5jzb2rhkd65b

Caruana, J., 2005, Basel II: Back to the future. 7th Hong Kong Monetary Authority Distinguished Lecture, viewed 07 September 2016, from www.bde.es/prensa/ intervenpub/gobernador/040205e.pdf.

Elizalde, A. \& Repullo, R., 2007, 'Economic and regulatory capital in banking: What is the difference?', International Journal of Central Banking 3(3), 87-117, viewed 07 September 2016, from: http://www.ijcb.org/journal/ijcb07q3a3.pdf.

Federal Reserve, 2003, Capital standards for banks: The evolving Basel Accord viewed 28 February 2017, from https://www.federalreserve.gov/pubs/bulletin/ 2003/0903lead.pdf.

Felsenfeld, C. \& Bilali, G., 2004, 'The role of the Bank for International Settlements in shaping the world financial system', University of Pennsy/vania Journal of International Law 25(1), 1-101. https://doi.org/10.2139/ssrn.496022

Ferguson, D., 2015, 'How safe are you and your bank from cyber-attack?', The Guardian, viewed 07 September 2016, from https://www.theguardian.com/ money/2015/feb/17/how-safe-you-bank-cyber-attack.

Frait, J. \& Tomsik, V., 2014, 'Impact and implementation challenges of the Base framework for emerging, developing and small economies', Comparative Economic Studies 56(4), 493-516. https://doi.org/10.1057/ces.2014.31
FSI (Financial Stability Institute), 2008, '2008 FSI Survey on the implementation of the new capital adequacy framework in non-Basel Committee member countries: Summary of responses to the Basel II implementation survey', Bank for countries: Summary of responses to

Gomes, T. \& Khan, N., 2011, 'Strengthening bank management of liquidity risk: The Basel III liquidity standards', Bank of Canada Financial System Review 5, 35-42.

Gomez, R. 2016, Financial regulation outlook January 2016: From Basel III to Basel IV? BBVA Research, viewed 12 September 2016, from https://www.bbvaresearch. com/en/?capitulo=from-basel-iii-to-basel-iv.

Gottschalk, R., 2010, The Basel Capital Accords in developing countries, viewed 12 September 2016, from http://0-www.palgraveconnect.com.oasis.unisa.ac.za/pc/ doifinder/10.1057/9780230276093.

Härle, P., Lüders, E., Pepanides, T., Pfetsch, S., Poppensieker, T. \& Stegemann, U. 2010, Basel III and European banking: Its impact, how banks might respond and the challenges of implementation, McKinsey Working Paper on Risk 26, and the chall 1-28, EMEA Banking, McKinsey \& Company management consultants, viewed 09 May 2019, from financial\%20services/our $\% 20$ insights $/$ basel $\% 20$ iii $\% 20$ now $\% 20$ the $\% 20$ hard\%20part\%20for\%20european\%20banks/26_basel_iii_and_european_ banking.ashx.

Herring, R.J., 2007, 'The rocky road to the implementation of Basel II in the US', Atlantic Economic Journal 35(4), 411-429. https://doi.org/10.1007/s11293-0079094-6

IBM, 2011, Banking data warehouse support for the Basel II and Basel III framework, White paper, BDW release 8.4, IBM Corporation, Somers, NY.

Jones, D., 2000, 'Emerging problems with the Basel Capital Accord: Regulatory capital arbitrage and related issues', Journal of Banking \& Finance 24, 35-58. https://doi. org/10.1016/S0378-4266(99)00052-7

KPMG, 2012, Africa Banking Survey, Johannesburg, South Africa.

Kundisch, D., Löhner, F.M., Rudolph, D., Steudner, M. \& Weiss, C., 2007, 'Bank management using Basel II data: Is the collection, storage and evaluation of data calculated with internal approaches dispensable?', paper presented at the Enterprise Risk Management Symposium, Society of Actuaries, 28-30 March, Chicago, IL.

Makuna, S., 2005, Regulation a necessary step in SA's growth. Business Report, viewed 12 November 2009, from http://www.busrep.co.za/Article3023243.

Marx, J. \& Mynhardt, R.H., 2011, 'The cost of compliance: The case of South African banks', Corporate Ownership and Control 8(3), 435-442. https://doi. org/10.22495/cocv8i3c4p1

McGarvey, C., 2007, Participatory action research, viewed 26 September 2018, from http://www.grantcraft.org/assets/content/resources/par.pdf.

McNiff, J. \& Whitehead, J., 2016, You and your action research project, 4th edn., Routledge, New York.

Mostert, J.W., 2013, 'A critical evaluation of the Basel III changed proposal on the liquidity coverage ratio', Unpublished PhD dissertation, University of the Free State, Bloemfontein.

Nyantakyi, E.B. \& Sy, M., 2015, 'The banking system in Africa: Main facts and challenges', Africa Economic Brief 6(5), 1-16.

Ojwang, G.O. 2015, 'Basel Accords on risk management: A survey of Kenya's commercial banks', Journal of Global Economics 3(4), 1-9. https://doi. org/10.4172/2375-4389.1000164

Schoenbaum, T.J., 2012, The age of austerity: The global financial crisis and return to economic growth, Edward Elgar, Northampton.

Toniolo, G. \& Clement, P., 2005, Central Bank Cooperation at the Bank for Internationa Settlements, 1930-1973, Cambridge University Press, Cambridge.

Veron, N., 2014, The European Union is the global laggard on Basel III, viewed 08 September 2016, from http://bruegel.org/2014/12/the-european-union-is-theglobal-laggard-on-basel-iii/ 